Research, part of a Special Feature on Understanding the Vulnerability and Sustainability of Urban Social-Ecological Systems in the Tropics: Perspectives from the City of San Juan

\title{
Spatio-temporal variation in stream water chemistry in a tropical urban watershed
}

\author{
Alonso Ramírez $^{1}, \underline{\text { Keysa G. Rosas }}{ }^{1}$, Ariel E. Lugo ${ }^{2}$ and Olga M. Ramos-González ${ }^{2}$
}

\begin{abstract}
Urban activities and related infrastructure alter the natural patterns of stream physical and chemical conditions. According to the Urban Stream Syndrome, streams draining urban landscapes are characterized by high concentrations of nutrients and ions, and might have elevated water temperatures and variable oxygen concentrations. Here, we report temporal and spatial variability in stream physicochemistry in a highly urbanized watershed in Puerto Rico. The main objective of the study was to describe stream physicochemical characteristics and relate them to urban intensity, e.g., percent impervious surface cover, and watershed infrastructure, e.g., road and pipe densities. The Río Piedras Watershed in the San Juan Metropolitan Area, Puerto Rico, is one of the most urbanized regions on the island. The Río Piedras presented high solute concentrations that were related to watershed factors, such as percent impervious cover. Temporal variability in ion concentrations lacked seasonality, as did all other parameters measured except water temperature, which was lower during winter and highest during summer, as expected based on latitude. Spatially, stream physicochemistry was strongly related to watershed percent impervious cover and also to the density of urban infrastructure, e.g., roads, pipe, and building densities. Although the watershed is serviced by a sewage collection system, illegal discharges and leaky infrastructure are probably responsible for the elevated ion concentration found. Overall, the Río Piedras is an example of the response of a tropical urban watershed after major sewage inputs are removed, thus highlighting the importance of proper infrastructure maintenance and management of runoff to control ion concentrations in tropical streams.
\end{abstract}

Key Words: ion concentrations; nutrient concentrations; Puerto Rico; tropical streams; urban streams; water physicochemistry

\section{INTRODUCTION}

Human activities have greatly transformed the environment and the planet, creating new conditions in which human systems are major factors (Ellis 2011). Urban areas are a type of extreme manifestation of human presence as they severely alter the natural landscape. Most urban effects on natural ecosystems are derived from their transformation of the landscape, i.e., conversion of natural vegetation to impermeable surfaces or the buildings themselves, and the production of wastes that change the flow of energy and matter in ecosystems, often altering ecosystem function (Pickett et al. 2011). As the human population increases its presence in cities, urban areas become important sources of ecosystem alteration (Alberti et al. 2003). Streams are particularly vulnerable because they integrate the landscape, and stream water physicochemical characteristics reflect both the geological setting that they drain and inputs from the surrounding watershed (Allan 2004). Urban streams show particular physicochemical signals that reflect the higher amounts of inputs they receive from the surrounding watershed (Hatt et al. 2004). Therefore, urban stream water chemistry can be used to gauge the effects that human activities have on the environment.

Urban streams share a series of characteristics that change little with geography. The "urban stream syndrome" is a conceptual model that summarizes urban effects and stream responses to urbanization (Meyer et al. 2005, Walsh et al. 2005). Common effects of urbanization on streams include, among others, altered channel geomorphology due to changes in sediment delivery, flashier hydrology associated with large amounts of impervious surfaces, the loss of native biota and increases in non-native species as the result of environmental changes (Walsh et al. 2005). In addition, most urban streams have increased solute concentrations, e.g., nutrients, ions, and contaminants, relative to forested streams (Paul and Meyer 2001). Among major nutrients, urbanization greatly increases nitrogen concentrations in streams and the overall nitrogen export to downstream ecosystems and coastal areas (Kaushal et al. 2008). Solute concentrations, in general, are positively related to the density of urban infrastructure on the watershed, e.g., roads, buildings, pipes. Studies in urban areas in Australia have shown that nitrogen concentrations in streams are related to sewage infrastructure on the watershed, such as septic tank density, whereas most solutes were strongly related to percent impervious surface in the watershed (Hatt et al. 2004).

Urban streams in tropical regions have received less attention, but the symptoms described for other urban regions are expected to be similar in the tropics. In tropical islands the urban stream syndrome applies in general, with some modifications (Ramírez et al. 2009). For example, urban streams in Puerto Rico and Hawaii have native faunas, in particular fishes and shrimp, that are less vulnerable to urban effects (Ramírez et al. 2012). Most native fishes and shrimps are able to maintain their populations in urban streams as long as they remain connected to estuaries where their larval stages develop (Brasher 2003, Ramírez et al. 2009). In addition, streams in the humid tropics do not show the expected increase in variability in discharge, i.e., flashiness, because of the frequent rainfall and saturated soils of these areas (Ramírez et al. 2009). On the other hand, water physicochemistry and solute concentrations follow the expected pattern of enriched values with increasing urbanization (Ramírez et al. 2009). In the Río Piedras Watershed, Puerto Rico, stream solute concentration increases as percent urban cover increases in the watershed (de Jesús-Crespo and Ramírez 2011). However, our understanding remains limited and the relation between urban infrastructure and stream solute concentrations has not been explored in tropical regions. 
Table 1. Land cover and structure densities for each study subwatershed in the Río Piedras watershed. Sites are ordered by increasing percent impervious surface area.

\begin{tabular}{|c|c|c|c|c|c|c|c|c|c|c|c|}
\hline \multirow[t]{2}{*}{$\begin{array}{l}\text { Site } \\
\text { No. }\end{array}$} & \multirow[t]{2}{*}{ Site Name } & Area & $\begin{array}{l}\text { Tree } \\
\text { Cover }\end{array}$ & $\begin{array}{l}\text { Pasture/ } \\
\text { Grass }\end{array}$ & $\begin{array}{c}\text { Impervious } \\
\text { Surface } \\
\text { (ISA) }\end{array}$ & Bare & $\begin{array}{l}\text { Water } \\
\text { bodies }\end{array}$ & $\begin{array}{c}\text { Water Pipe } \\
\text { Density }\end{array}$ & $\begin{array}{c}\text { Sewage Pipe } \\
\text { Density }\end{array}$ & $\begin{array}{c}\text { Road } \\
\text { Density }\end{array}$ & $\begin{array}{c}\text { Structure } \\
\text { Density }\end{array}$ \\
\hline & & $\left(\mathrm{km}^{2}\right)$ & $(\%)$ & $(\%)$ & $(\%)$ & $(\%)$ & $(\%)$ & $\left(\mathrm{m} / \mathrm{km}^{2}\right)$ & $\left(\mathrm{m} / \mathrm{km}^{2}\right)$ & $\begin{array}{c}(\mathrm{m} / \\
\left.\mathrm{km}^{2}\right) \\
\end{array}$ & $\left(\mathrm{no} . / \mathrm{km}^{2}\right)$ \\
\hline 1. & $\begin{array}{l}\text { Quebrada Las } \\
\text { Curías }\end{array}$ & 4.11 & $61.34 \%$ & $21.73 \%$ & $12.90 \%$ & $0.07 \%$ & $3.95 \%$ & 1691.59 & 23.37 & 5549.43 & 222.50 \\
\hline 2. & Montehiedra & 3.83 & $41.20 \%$ & $20.49 \%$ & $38.20 \%$ & $0.07 \%$ & $0.04 \%$ & 7832.99 & 3374.35 & 9338.90 & 351.29 \\
\hline 3. & La Sierra & 20.83 & $45.04 \%$ & $19.01 \%$ & $35.05 \%$ & $0.08 \%$ & $0.82 \%$ & 6506.95 & 4328.65 & 9271.60 & 428.58 \\
\hline 4. & Río Piedras & 0.19 & $43.48 \%$ & $7.93 \%$ & $48.50 \%$ & $0.09 \%$ & $0.00 \%$ & 13955.73 & 13057.92 & 18784.37 & 2002.67 \\
\hline 5. & Correo de Cupey & 1.68 & $26.59 \%$ & $15.34 \%$ & $58.02 \%$ & $0.05 \%$ & $0.00 \%$ & 12482.75 & 11030.05 & 13816.06 & 749.75 \\
\hline 6. & Avenida Central & 40.33 & $34.13 \%$ & $17.73 \%$ & $47.54 \%$ & $0.08 \%$ & $0.51 \%$ & 8910.05 & 8245.83 & 11873.14 & 660.08 \\
\hline 7. & San Patricio & 3.16 & $9.61 \%$ & $13.15 \%$ & $77.15 \%$ & $0.09 \%$ & $0.00 \%$ & 15446.08 & 15558.38 & 17144.81 & 1754.77 \\
\hline 8. & Las Lomas & 7.93 & $17.29 \%$ & $16.62 \%$ & $65.94 \%$ & $0.07 \%$ & $0.07 \%$ & 12849.57 & 10899.57 & 14478.61 & 692.77 \\
\hline
\end{tabular}

We monitored stream water physicochemistry weekly in an urbanized tropical watershed in Puerto Rico. The Río Piedras is a highly urbanized watershed draining the San Juan Metropolitan Area in Puerto Rico, the most urbanized region on the island. Our main goal was to characterize temporal and spatial variability in stream water physicochemistry in this highly affected and understudied area. In addition, we also assessed which watershed characteristics, e.g., imperviousness, infrastructure density, or amount of green areas, were related to variation in stream water physicochemistry. The overarching goal of the study is to understand how human activities are transforming stream ecosystems in the Río Piedras Watershed, and how those transformations might in turn affect ecosystem services and human health.

\section{METHODS}

\section{Study watershed}

The Río Piedras Watershed drains a large portion of the San Juan Metropolitan Area (SJMA) in Puerto Rico. San Juan is highly urbanized, with a population density of around 3190 people $/ \mathrm{km}^{2}$ (U.S. Census Bureau 2010). The watershed originates at about 150 m.a.s.l. and has a steep gradient within its first $8 \mathrm{~km}$ before it reaches the lowlands (de Jesús-Crespo and Ramírez 2011). The river has been greatly modified by human activities, and even watershed area has changed over time because of flow alterations. Haire (1971) describes the Río Piedras as having a watershed area of $49 \mathrm{~km}^{2}$ in the $1970 \mathrm{~s}$, contrasting with our latest measurements of $67 \mathrm{~km}^{2}$ (de Jesús-Crespo and Ramírez 2011), the difference representing the large number of modifications that the river has undergone, in particular at the lowest reaches where the Puerto Nuevo river joins the main stem of the Río Piedras River (Lugo et al. 2011). In addition, the watershed has been affected by channelization and concrete lining in numerous tributaries, paving over ephemeral and intermittent streams, and considerable land movements that have reshaped the local topography (Lugo et al. 2011). Impervious surfaces now reach $49 \%$ of the total area (de Jesús-Crespo and Ramírez 2011), which results in high runoff rates, e.g., 72\% of rainfall becomes stream flow (Osterkamp 2001). Urbanization in the SJMA started in the coastal areas, thus the
Río Piedras Watershed is more heavily urbanized in lowland areas and more rural at its headwaters. Currently, most of the watershed is serviced by a municipal water system for drinking water (Table 1). Although sewage collection is provided for a large percentage of the area, some areas in the headwaters rely on septic systems. Also, sewage and storm water are supposedly collected separately, but combined systems are present and sewage inputs into streams are evident after heavy rains.

We selected eight sites within the Río Piedras Watershed (Fig. 1), each site associated with focal study areas by the San Juan ULTRA program (http://sanjuanultra.com/). Selected tributaries were easily accessed at a road crossing to conduct the ongoing weekly water sampling. Six of the selected sites are small tributaries with clearly delineated subwatersheds, whereas two are located in the main stem of the river. The two main stem sites were selected in close proximity of a United States Geological Survey (USGS) gaging station. The first (site 3) is located near the USGS 50048770 Río Piedras at El Señorial station, which is located 60 m.a.s.l., drains $19.4 \mathrm{~km}^{2}$, and reports an average yearly discharge of $0.61 \mathrm{~m}^{3} / \mathrm{sec}$ (18-year record). The second site (site 6 ) is located at the USGS 50049100 Río Piedras at Hato Rey station, which is located just above sea level (1 m.a.s.l), drains $39.4 \mathrm{~km}^{2}$, and reports an average yearly discharge of $1.6 \mathrm{~m}^{3} / \mathrm{sec}$ (23-year record).

\section{Land cover analysis}

The subwatershed of each sampling site was delimited using the Arc GIS 9.3.1 hydrology tool of the Spatial Analyst Extension and the 30m Puerto Rico Digital Elevation Model. Using ArcMap 9.3.1., we intersected each subwatershed with available geodatasets for water and sewer lines, streets and roads lines, and building footprint polygons. Water and sewer line data from 2009 was obtained from the Puerto Rico Aqueduct and Sewer Authority, the roads and streets data from the Federal Census Bureau 2006 TIGER line files, and the structures and the buildings data from 1998 from the Puerto Rico Municipal Revenue Center. We used a 4-meter resolution land cover classification (American Forests 2002) that included impervious surface, tree cover, pasture and grass, bare surface, and water 
bodies to calculate areal extents and impervious surface percentages for each subwatershed.

Fig. 1. Map of the Río Piedras Watershed and Puerto Rico. The study subwatersheds are delimited based on a $30 \mathrm{~m}$ digital elevation model. Site numbers as in Table 1.

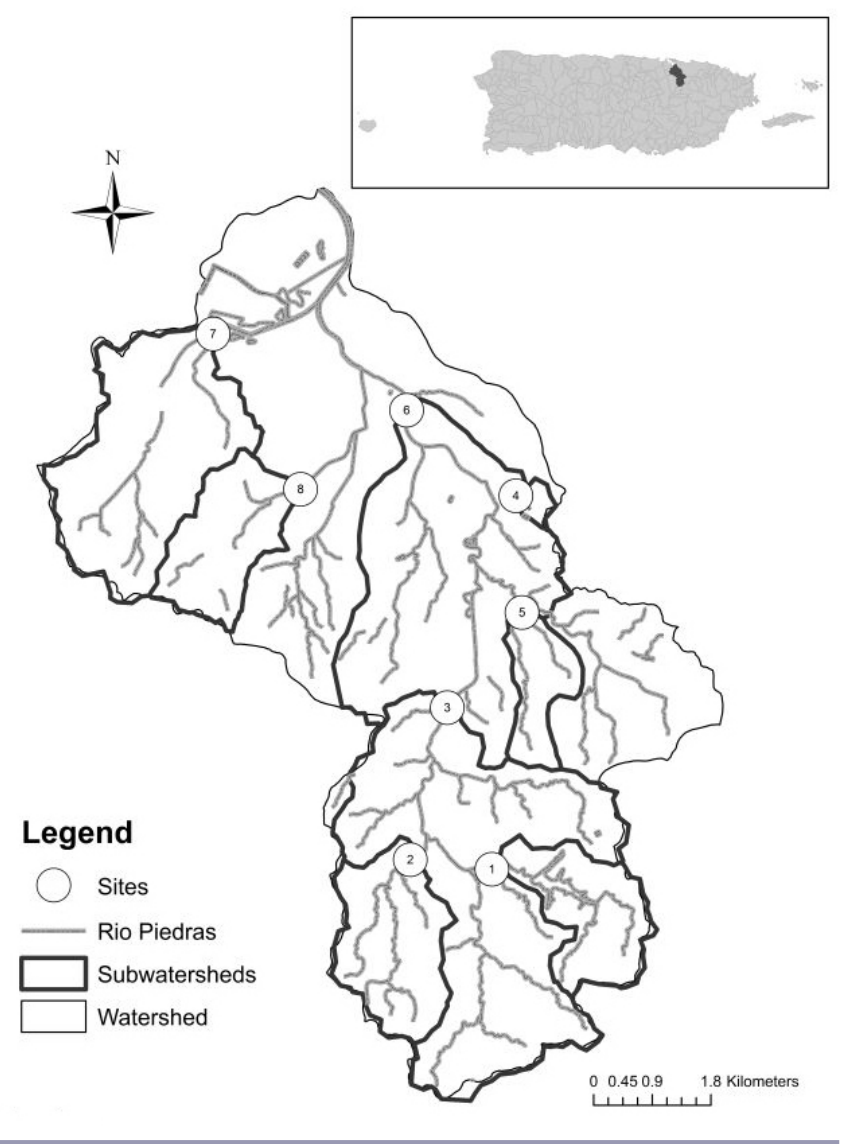

\section{Sample collection}

Water samples were collected at each study site weekly on Tuesday, from April 2011 to the present. We report in this study the first year of data ending in April 2012. Samples were collected from the center of the channel, kept in a cooler, filtered through precombusted $0.70-\mu \mathrm{m}$ glass fiber filters, and frozen in plastic bottles until analyzed. We determined major ion concentrations $\left(\mathrm{Na}^{+}, \mathrm{Ca}^{2+}, \mathrm{NH}_{4}^{+}, \mathrm{Mg}^{+}, \mathrm{K}^{+}, \mathrm{Cl}^{-}, \mathrm{SO}_{4}{ }^{2-}, \mathrm{NO}_{3}^{-}\right)$with an ICS-3000 Ion Chromatography System (Dionex Corporation, Sunnyvale, California, USA). The U.S. Forest Service Laboratory in Río Piedras conducted all water chemistry analyses. We measured $\mathrm{pH}$, specific conductivity, and temperature in the field using a YSI Model 63 multiparameter instrument (YSI Incorporates, Yellow Springs, Ohio, USA).

\section{Statistical analyses}

We calculated average, standard deviation, minimum and maximum for each variable measured as a way to characterize their variability. We used stepwise multiple regressions to identify which land cover variables were related to stream solute concentrations or physicochemical parameters. We recognize that multiple regression has limitations, in particular given our sample size of eight sites, but we consider the analysis valid as an exploratory tool. To complement, we used principal components analysis (PCA) to order our study sites along gradients (i.e., PCA axis) in stream solute concentration and physicochemistry. We then related this gradient, or PCA axis, with land cover variables using linear regressions. PCA was run in PC-Ord Software (McCune and Mefford 1999) and regression and multiple regressions in R ( $\mathrm{R}$ Development Core Team 2014).

\section{RESULTS}

\section{Land cover analysis}

Our study subwatersheds ranged from 13 to $77 \%$ in impervious surface cover, 10 to $59 \%$ in tree cover, and 7 to $22 \%$ in pasture/ grass cover (Table 1). For the purposes of our study, tree cover and pasture/grass cover were combined into a single category called vegetation. The study subwatersheds ranged from 23 to $81 \%$ vegetation cover. Quebrada Las Curías (site 1), located in the upper part of the watershed, had the highest vegetation cover and lowest density of structures, e.g., buildings and roads. In addition, it was the only site that was not served by the municipal sewer network (Table 1). The remaining sites increased in structure density, i.e., sewer and water pipe density, roads, and buildings, as impervious surface cover increased. There was a leveling at $50 \%$ impervious surface are (ISA), after which densities did not increase as much (Table 1).

\section{Water physicochemistry and solutes}

Sites varied in their solute concentrations and water physicochemistry (Table 2), but the range of that variation was relatively similar among study sites (Fig. 2). An exception was the least urbanized site 1 , which had lower ion concentrations and conductivity and relatively higher $\mathrm{NO}^{3}$ concentrations than the rest (Fig. 2). Over time, stream discharge was highly variable at the Río Piedras watershed and a dry-wet season pattern cannot be delineated (Fig. 3). However, base flow was clearly higher from May to November, coinciding with the period normally known as the rainy season. Among physicochemical variables and solutes, only water temperature showed a clear seasonal pattern, i.e., lowest in January, highest in July, with the rest fluctuating without seasonality (Fig. 4). A case could be made that calcium exhibited a decrease in concentration in weeks 5 through 20 (MayAugust 2011), which coincide with the period of elevated based flow and the largest peaks in discharge (Fig. 4).

\section{Water chemistry vs. watershed land cover}

All stream solutes and physicochemistry were related to measures of subwatershed land cover and structure density to some degree (Table 3). Sewage pipe and structure densities on the subwatershed were the variables most often related to water chemical parameters, being related with all solutes, except for nitrogen (Table 3). Some relations were expected, for example, increasing vegetation on the subwatershed was related to a decrease in ammonium and an increase in the variability of water conductivity. Other relationships were unexpected and perhaps confounded by other factors. For example, chloride increased in relation to an increase in sewage pipe densities and impervious surface area, but it was also related to an increase in vegetation cover (Table 3). Similarly, water pipe density was related to an increase in sulfate and a decrease in magnesium. Sewage pipe 
Table 2. Mean chemical concentration of anions and cations, and physicochemical variables at each study site in the Río Piedras watershed. Site numbers as in Table 1. Cation and anion means are based on 50 collections, except site 9, which is based on 51, and site 8 , which is based on 43. Temperature, specific conductivity, and $\mathrm{pH}$ means are based on 53 collection dates. Data correspond to weekly collections between 21 April 2011 and 17 April 2012. Avg = average value, Stdev = standard deviation, Min = minimum value, Max = maximum value, Temp $=$ temperature, SpCond $=$ specific conductivity.

\begin{tabular}{|c|c|c|c|c|c|c|c|c|c|c|c|c|}
\hline \multirow{2}{*}{$\begin{array}{l}\text { Site } \\
\text { No. }\end{array}$} & & $\mathrm{Cl}^{-}$ & $\mathrm{SO}_{4}^{--}$ & $\mathrm{NO}_{3}^{-}$ & $\mathrm{Na}^{+}$ & $\mathrm{NH}_{4}^{+}$ & $\mathrm{K}^{+}$ & $\mathrm{Mg}^{+}$ & $\mathrm{Ca}^{++}$ & Temp & SpCond & $\mathrm{pH}$ \\
\hline & & (ppm) & (ppm) & (ppm) & (ppm) & (ppm) & (ppm) & (ppm) & (ppm) & $\left({ }^{\circ} \mathrm{C}\right)$ & $(\mu \mathrm{S})$ & \\
\hline \multirow[t]{4}{*}{1.} & Avg & 18.59 & 7.97 & 3.42 & 16.10 & 0.06 & 2.28 & 8.67 & 17.06 & 25.50 & 239.61 & 7.54 \\
\hline & Stdev & 4.11 & 1.90 & 1.74 & 3.12 & 0.07 & 0.35 & 1.35 & 3.80 & 1.48 & 52.64 & 0.30 \\
\hline & Min & 12.14 & 3.93 & 0.20 & 10.95 & 0.00 & 1.77 & 5.79 & 9.32 & 22.90 & 109.00 & 6.96 \\
\hline & Max & 32.45 & 12.44 & 7.94 & 23.78 & 0.26 & 3.57 & 12.10 & 27.43 & 28.12 & 353.00 & 7.97 \\
\hline \multirow[t]{4}{*}{2.} & Avg & 24.53 & 14.83 & 3.65 & 22.99 & 0.13 & 2.86 & 12.38 & 25.67 & 24.92 & 368.40 & 7.92 \\
\hline & Stdev & 4.71 & 3.07 & 0.70 & 4.26 & 0.45 & 0.43 & 2.31 & 6.47 & 1.30 & 79.19 & 0.18 \\
\hline & Min & 8.16 & 4.27 & 1.12 & 8.21 & 0.00 & 2.21 & 4.40 & 12.01 & 22.40 & 121.50 & 7.38 \\
\hline & Max & 32.50 & 21.36 & 5.36 & 30.96 & 2.87 & 4.08 & 16.69 & 40.24 & 27.81 & 480.00 & 8.16 \\
\hline \multirow[t]{4}{*}{3.} & Avg & 23.56 & 13.15 & 3.47 & 20.69 & 0.25 & 2.67 & 10.51 & 25.01 & 24.96 & 334.21 & 7.95 \\
\hline & Stdev & 4.58 & 2.65 & 0.80 & 3.98 & 0.28 & 0.41 & 2.18 & 4.48 & 1.44 & 75.89 & 0.47 \\
\hline & Min & 9.90 & 5.47 & 1.22 & 9.28 & 0.00 & 2.04 & 3.91 & 14.23 & 22.10 & 169.00 & 5.52 \\
\hline & $\operatorname{Max}$ & 30.69 & 17.72 & 5.15 & 26.95 & 1.43 & 3.90 & 13.61 & 33.45 & 27.65 & 435.40 & 8.42 \\
\hline \multirow[t]{4}{*}{4.} & Avg & 33.63 & 13.77 & 3.48 & 22.82 & 0.92 & 3.75 & 7.32 & 25.99 & 26.50 & 312.23 & 7.33 \\
\hline & Stdev & 7.41 & 3.53 & 0.83 & 5.95 & 0.55 & 0.45 & 2.14 & 5.42 & 1.16 & 93.07 & 0.27 \\
\hline & Min & 11.37 & 7.29 & 1.27 & 8.83 & 0.10 & 2.37 & 1.81 & 10.74 & 24.00 & 63.50 & 6.73 \\
\hline & Max & 50.29 & 24.28 & 6.13 & 37.61 & 2.53 & 4.94 & 11.49 & 39.55 & 28.46 & 491.00 & 8.01 \\
\hline \multirow[t]{4}{*}{5.} & Avg & 27.98 & 10.68 & 4.54 & 22.95 & 0.37 & 2.38 & 8.68 & 30.00 & 25.59 & 374.08 & 7.51 \\
\hline & Stdev & 7.34 & 2.89 & 1.05 & 5.32 & 0.39 & 0.42 & 2.06 & 7.04 & 1.14 & 92.95 & 0.22 \\
\hline & Min & 9.67 & 4.01 & 1.68 & 9.35 & 0.10 & 1.85 & 3.42 & 15.09 & 23.20 & 133.10 & 6.98 \\
\hline & Max & 40.53 & 20.28 & 7.01 & 31.41 & 2.15 & 3.62 & 11.47 & 41.56 & 27.83 & 503.00 & 7.77 \\
\hline \multirow[t]{4}{*}{6.} & Avg & 26.16 & 12.32 & 3.41 & 22.10 & 0.91 & 2.80 & 9.08 & 25.91 & 26.52 & 350.99 & 7.76 \\
\hline & Stdev & 6.47 & 2.80 & 0.84 & 4.96 & 0.56 & 0.37 & 1.92 & 5.76 & 1.39 & 80.98 & 0.25 \\
\hline & Min & 10.31 & 5.70 & 1.66 & 10.09 & 0.27 & 2.00 & 4.63 & 14.45 & 23.40 & 108.80 & 7.25 \\
\hline & Max & 39.70 & 18.58 & 5.04 & 31.44 & 3.38 & 3.77 & 12.16 & 39.42 & 28.82 & 469.00 & 8.82 \\
\hline \multirow[t]{4}{*}{7.} & Avg & 23.07 & 14.81 & 2.56 & 16.77 & 1.14 & 2.67 & 6.72 & 27.98 & 27.34 & 314.83 & 7.43 \\
\hline & Stdev & 4.57 & 3.45 & 0.90 & 3.26 & 0.60 & 0.35 & 1.64 & 5.93 & 1.49 & 69.28 & 0.16 \\
\hline & Min & 4.05 & 2.35 & 0.70 & 3.60 & 0.18 & 1.71 & 1.06 & 8.74 & 24.60 & 89.00 & 6.98 \\
\hline & Max & 29.95 & 19.38 & 3.96 & 21.22 & 3.33 & 3.41 & 8.93 & 35.60 & 29.99 & 405.00 & 7.71 \\
\hline \multirow[t]{4}{*}{8.} & Avg & 27.35 & 11.04 & 4.87 & 20.01 & 1.52 & 3.21 & 7.21 & 22.81 & 27.16 & 305.92 & 7.75 \\
\hline & Stdev & 6.05 & 3.02 & 1.85 & 4.21 & 2.61 & 0.58 & 1.79 & 4.48 & 1.54 & 80.85 & 0.25 \\
\hline & Min & 4.06 & 2.33 & 0.38 & 3.38 & 0.00 & 1.72 & 1.02 & 9.32 & 23.80 & 74.30 & 7.15 \\
\hline & Max & 36.89 & 25.16 & 7.49 & 26.96 & 11.53 & 4.73 & 9.77 & 29.88 & 29.41 & 433.40 & 8.44 \\
\hline
\end{tabular}

density was related to an increase in chloride, sulfate, temperature, and conductivity and a decrease in potassium (Table 3 ). Road density was related only to an increase in magnesium variability (Table 3). Nitrate and $\mathrm{pH}$ did not exhibit a relation to any of the parameters studied.

Principal Component Analysis (PCA) formed two major gradients in stream physicochemistry and solutes that explained $66 \%$ of the variance (Fig. 5). Based on the broken stick eigenvalue method, both axes are interpretable. PCA axis 1 explained $34.1 \%$ and formed a gradient of increasing chloride, sulfate, sodium, and calcium concentration and specific conductivity. PCA axis 2 explained an additional $32.4 \%$ and formed a gradient of increasing sodium, magnesium, specific conductivity, and $\mathrm{pH}$ and decreasing ammonium and temperature (Fig. 5). The sites possessed a spatial organization where Quebrada Las Curías was markedly different from the other sites. Montehiedra and La Sierra, Correo de Cupey and Avenida Central, and San Patricio and Las Lomas also formed slight clusters.
PCA axis 1 was negatively related to all of the parameters related to urban cover, i.e., ISA, water and sewage pipe density, road density and structure density, and was positively related to percent vegetation cover on the watershed (Fig. 6). Therefore, increasing concentrations of chloride, sulfate, sodium, calcium, and specific conductivity were related with increasing urban cover parameters and decreasing vegetation cover (Fig. 6).

\section{DISCUSSION}

The signature of human activities on the watershed is clearly reflected in the water chemistry of streams draining the Río Piedras. Urban streams often have high solute concentrations relative to forested streams, a well-known characteristic that is described as part of the urban stream syndrome (Walsh et al. 2005). Most water chemistry variables in our study streams reached values that clearly reflected a strong level of urban influence. Solute concentrations in the Río Piedras were in general accordance with previous studies that sampled either tributaries or the main stem of the river (Kwak et al. 2007, de Jesús-Crespo and Ramírez 2011, Potter et al. 2013). In addition, relative to other 
Fig. 2. Box and whisker plots of the variability in representative stream physicochemical parameters in the Río Piedras Watershed.
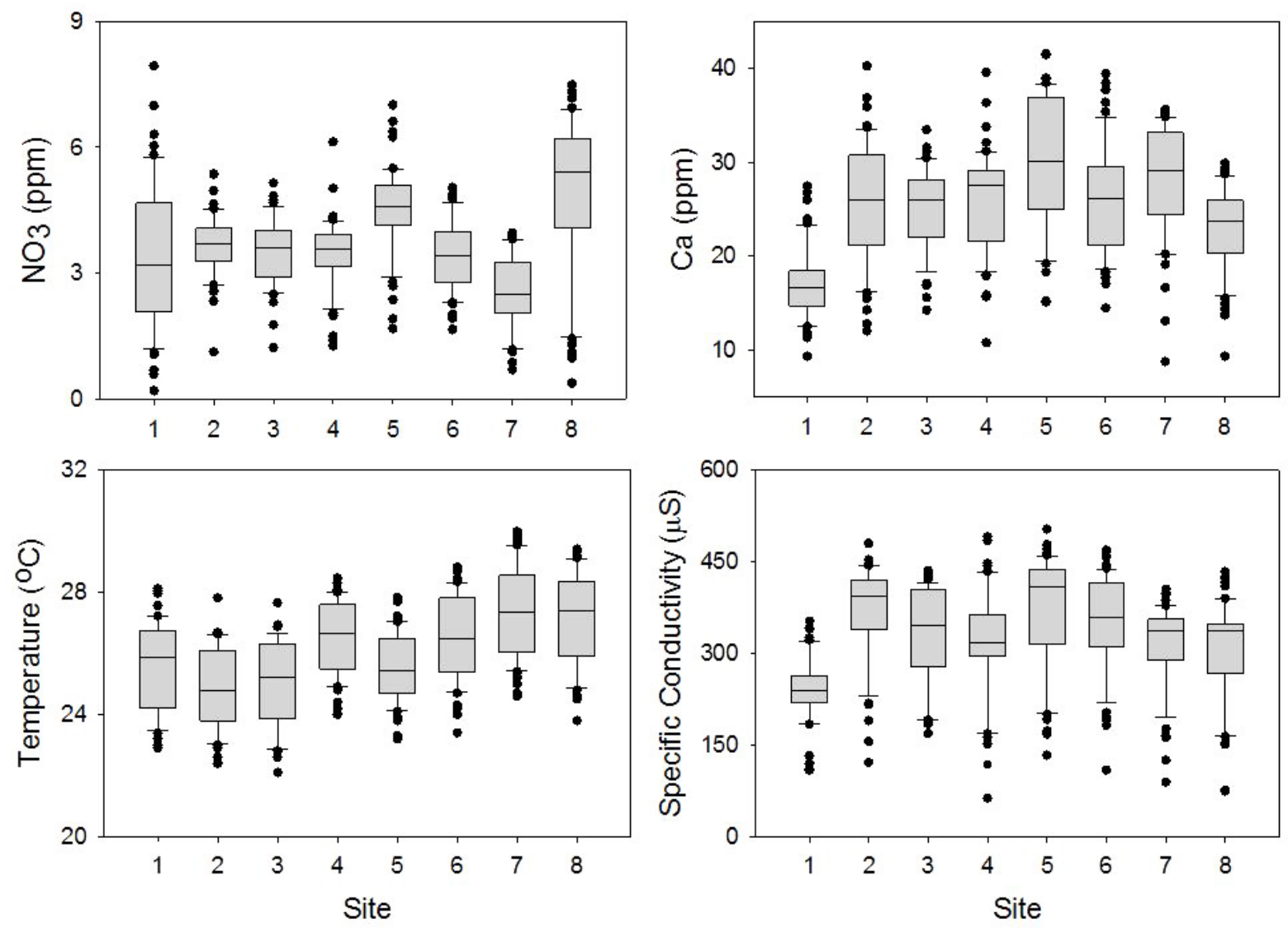

Fig. 3. Daily discharge at the Río Piedras based on records from U.S. Geological Survey station 50048770 at El Señorial station, which is located 60 m.a.s.1., drains $19.4 \mathrm{~km}^{2}$.

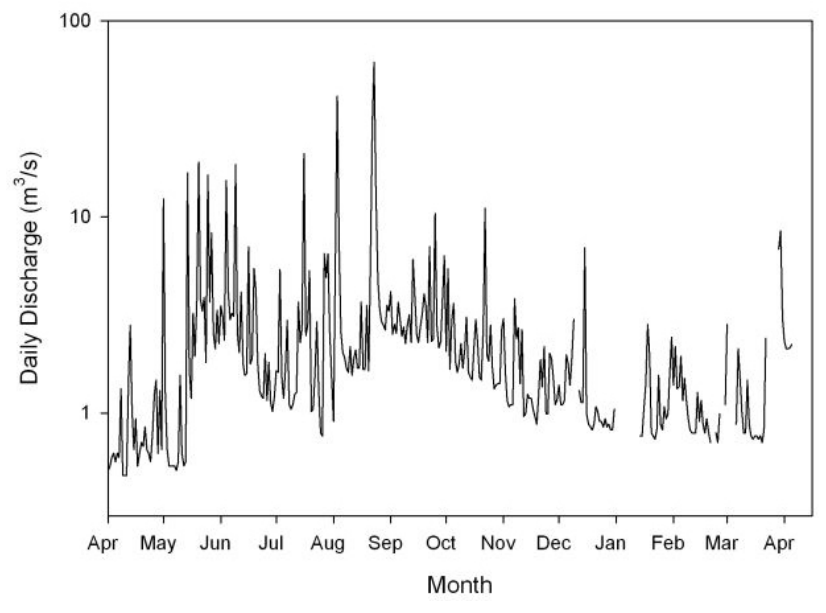

watersheds in Puerto Rico, the Río Piedras shares a chemical signature similar to streams in other urban areas. Santos-Román et al. (2003) analyzed the water signature of 15 watersheds in Puerto Rico and grouped them in 5 clusters that represented watersheds with similar water physicochemical characteristics. Our results fall within their "urban-polluted" cluster, with sodium levels in the highest range and conductivity in a moderate range.

Relative to nonurban streams, most solutes in this urban watershed are in concentrations at least four times greater than those reported for forested watersheds in Puerto Rico (McDowell and Ashbury 1994). Among all solutes, calcium was found at particularly high levels in the Río Piedras, with average values ranging from 17 to $30 \mathrm{mg} / \mathrm{L}$. Values in nearby forested streams in Puerto Rico are often below $7 \mathrm{mg} / \mathrm{L}$ (McDowell and Ashbury 1994). In addition, a study in three Caribbean island rivers, which are subjected to human effects, such as in agriculture and small towns, also reported average values ranging from 2.5 to $9 \mathrm{mg} / \mathrm{L}$ (McDowell et al. 1995). Although there are several possible sources of calcium in the watershed, it is possible that our elevated calcium values are due to the dissolution or chemical weathering of concrete found in the watershed, e.g., structures, other impervious surfaces, and channelized reaches. Several studies have documented the effects of concrete on stream water 
Fig. 4. Temporal weekly patterns for some representative stream physicochemical variables in the Río Piedras Watershed.
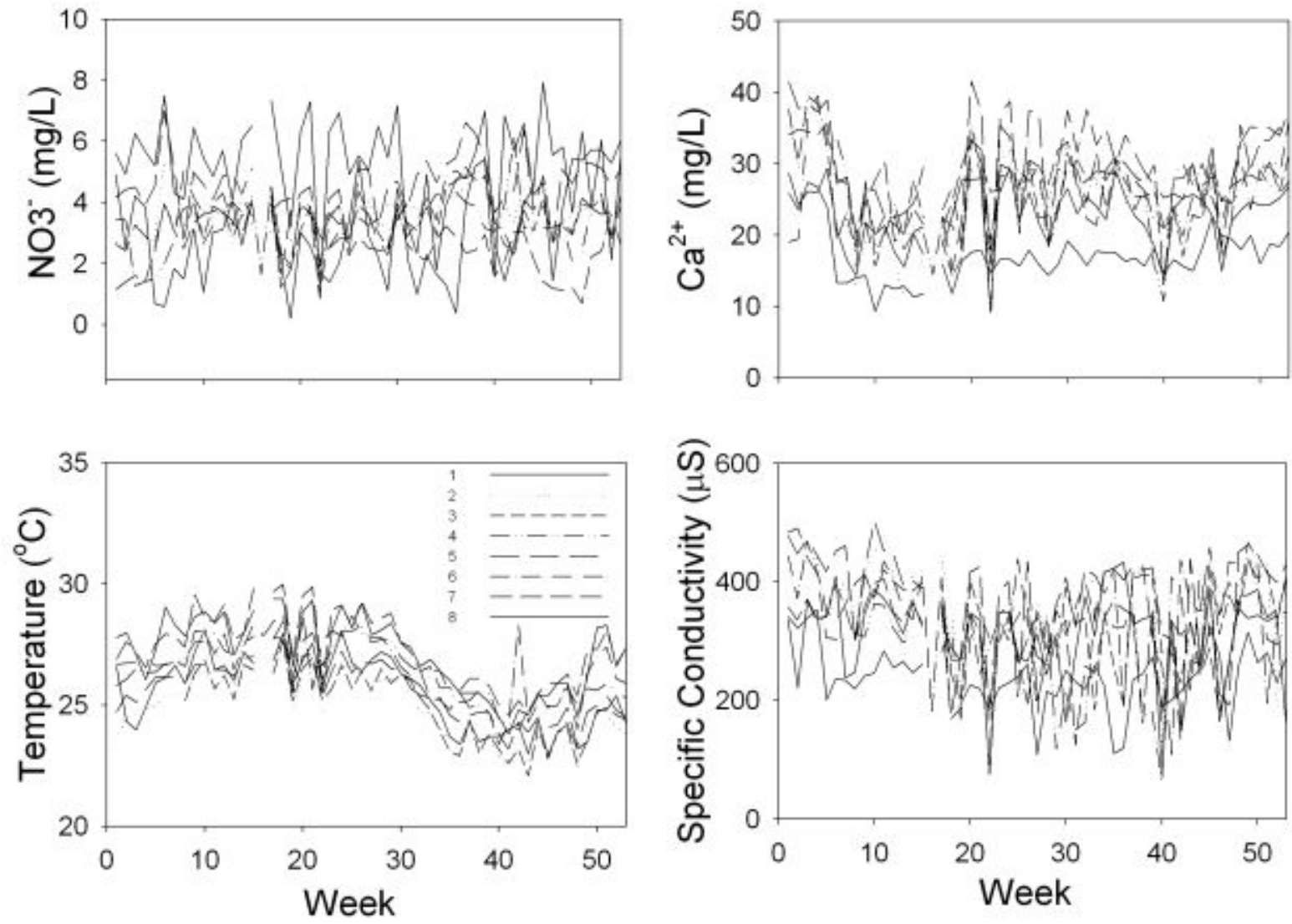

Fig. 5. Principal Component Analysis (PCA) of study sites based on water physicochemistry. Axis 1 explained $34.1 \%$ of the variance and axis 2 explained an additional $32 \%$ of the variance. Numbers refer to study sites as in Table 1.

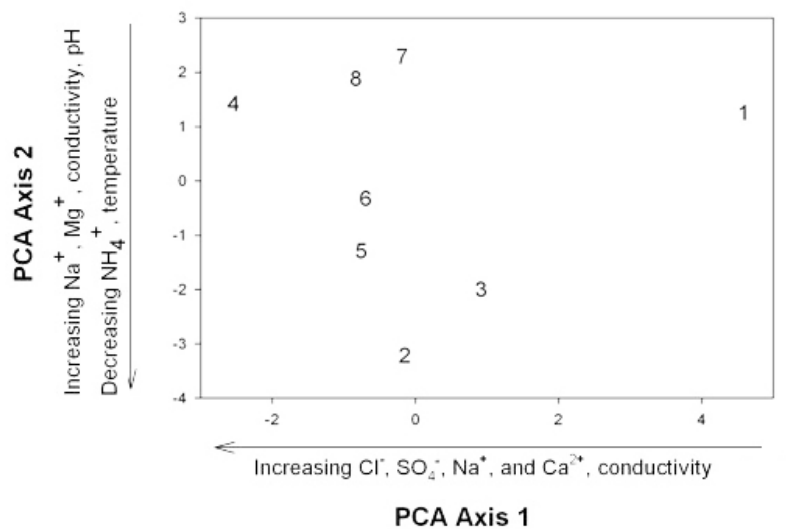

chemistry and its increase in calcium concentrations (Leung and Jiao 2006, Davies et al. 2010, Wright et al. 2011, Tippler et al. 2012). For example, Tippler et al. (2012) found that in streams with high imperviousness, calcium concentrations were more than nine times that of less impervious streams (20 mg/L vs. $2.2 \mathrm{mg} /$ L). These studies also found that the amount of concrete also results in increases in $\mathrm{pH}$, conductivity, bicarbonate, and potassium. Among other common ions, chloride, sodium, potassium, and magnesium were also found in concentrations much higher than those of forested streams. Most of these ions were in concentrations an order of magnitude higher than forested streams in Puerto Rico and other Caribbean islands (McDowell and Asbury 1994, McDowell et al. 1995). These ions are generally found to be elevated in urban streams (Paul and Meyer 2001), and the combined effect of their high concentration results in the elevated conductivity observed in most urban streams, as was seen in our study.

Nitrogen is an important nutrient that can strongly affect stream ecosystem function and it is commonly found in high concentrations in urban streams (Walsh et al. 2005). In the Río Piedras, we found elevated nitrate and ammonium concentrations relative to forested streams. However, concentrations were not related to watershed land cover or structure densities. This finding 
Fig. 6. Regression analysis between watershed infrastructure density and Principal Component Analysis (PCA) axis 1. (A) percent impervious surface area (ISA) versus Axis $1(\mathrm{r} 2=0.66, \mathrm{p}=0.01),(\mathrm{B})$ percent vegetation versus Axis $1(\mathrm{r} 2=0.62, \mathrm{p}=0.02),(\mathrm{C})$ sewage pipe density versus Axis $1(\mathrm{r} 2=0.68, \mathrm{p}=0.01)$, (D) drinking pipe density versus Axis $1(\mathrm{r} 2=0.78, \mathrm{p}<0.01)$, (E) road density versus Axis $1(\mathrm{r} 2=0.78, \mathrm{p}<0.01),(\mathrm{F})$ building density versus Axis $1(\mathrm{r} 2=0.51, \mathrm{p}=0.04)$.
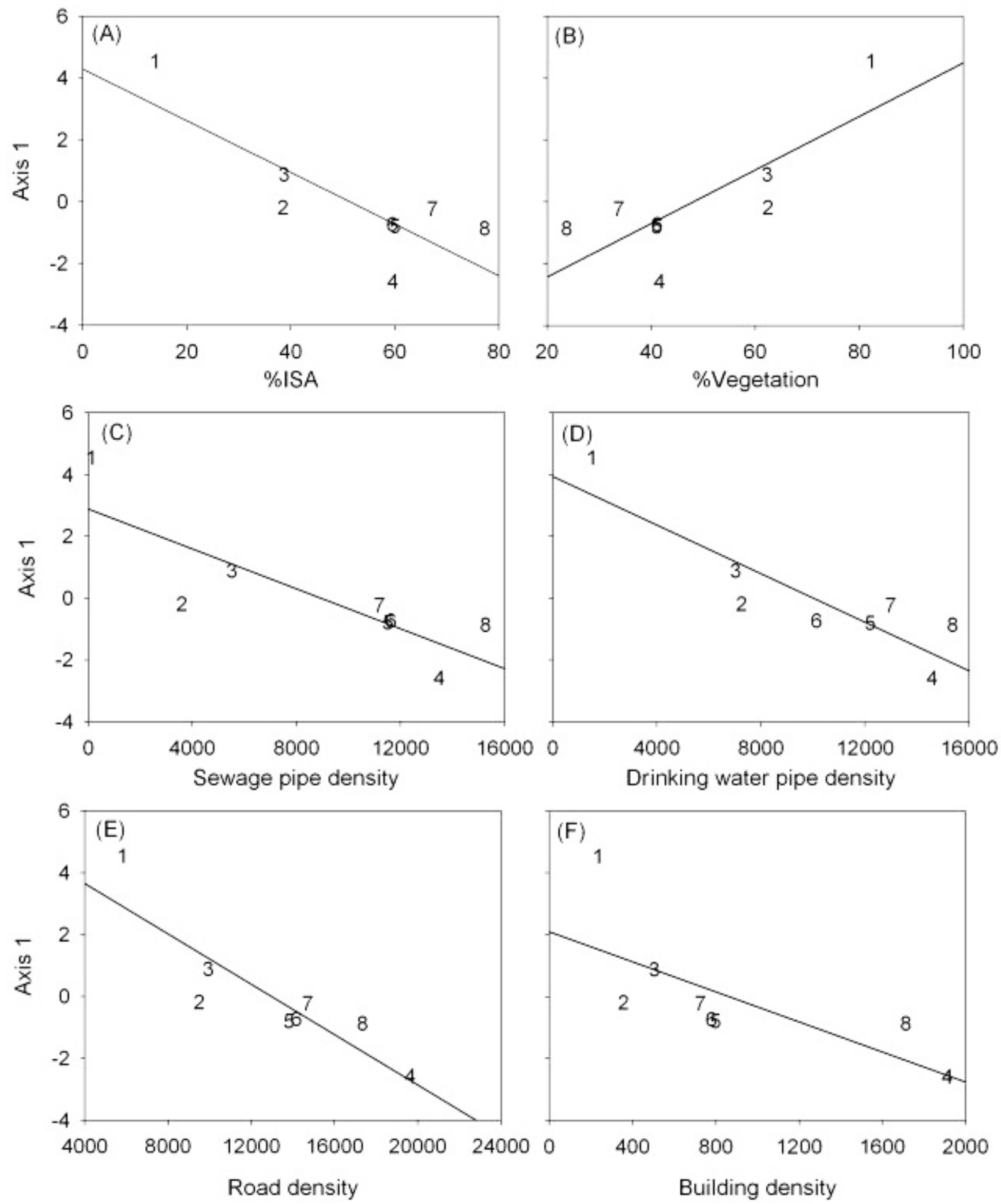
Table 3. $P$ values for stepwise multiple regression results between water variables and subwatershed characteristics. NS refers to a variable that entered the model, but was not significant at $p<0.10$. Values followed by (-) indicate negative relationships, all others being positive. Avg = average value, $\mathrm{CV}=$ coefficient of variation, Min = minimum value, $\mathrm{Max}=$ maximum value, Temp $=$ temperature, SpCond $=$ specific conductivity.

\begin{tabular}{|c|c|c|c|c|c|c|c|}
\hline \multirow[t]{2}{*}{ Variable } & & $\begin{array}{c}\text { Impervious } \\
\text { Surface (ISA) }\end{array}$ & Vegetation & $\begin{array}{c}\text { Water Pipe } \\
\text { Density }\end{array}$ & $\begin{array}{c}\text { Sewage Pipe } \\
\text { Density }\end{array}$ & Road Density & $\begin{array}{c}\text { Structure } \\
\text { Density }\end{array}$ \\
\hline & & $(\%)$ & $(\%)$ & $\left(\mathrm{m} / \mathrm{km}^{2}\right)$ & $\left(\mathrm{m} / \mathrm{km}^{2}\right)$ & $\left(\mathrm{m} / \mathrm{km}^{2}\right)$ & $\left(\mathrm{no} . / \mathrm{km}^{2}\right)$ \\
\hline \multirow[t]{4}{*}{$\mathrm{Cl}^{-}$} & Avg & 0.02 & 0.02 & NS & 0.03 & NS & NS \\
\hline & $\mathrm{CV}$ & & & & & & \\
\hline & Min & & NS & & 0.04 & & \\
\hline & Max & & & & & & 0.03 \\
\hline \multirow[t]{4}{*}{$\mathrm{SO}^{2-}$} & Avg & & & & & & \\
\hline & $\mathrm{CV}$ & & & & 0.04 & & \\
\hline & Min & & & & & & \\
\hline & Max & & & $<0.01$ & & & \\
\hline \multirow[t]{4}{*}{$\mathrm{NH}_{4}^{+}$} & Avg & & $<0.01(-)$ & & & & \\
\hline & $\mathrm{CV}$ & & & & & & \\
\hline & Min & & & & & & \\
\hline & $\operatorname{Max}$ & NS & NS & & & & NS \\
\hline \multirow[t]{4}{*}{$\mathrm{Mg}^{+}$} & Avg & & & & NS & & \\
\hline & $\mathrm{CV}$ & & & & & 0.01 & \\
\hline & Min & & & $<0.01(-)$ & & & \\
\hline & Max & & & & & & \\
\hline \multirow[t]{4}{*}{$\mathrm{Na}^{+}$} & Avg & & & & & & \\
\hline & $\mathrm{CV}$ & & & & & & 0.04 \\
\hline & Min & & & & & & \\
\hline & Max & & & & & & \\
\hline \multirow[t]{4}{*}{$\mathrm{Ca}^{2+}$} & Avg & & NS & NS & & & $0.03(-)$ \\
\hline & $\mathrm{CV}$ & & & & & & \\
\hline & Min & & & & & & \\
\hline & $\operatorname{Max}$ & & & & & & \\
\hline \multirow[t]{4}{*}{$\mathrm{K}^{+}$} & Avg & NS & NS & NS & $0.04(-)$ & NS & 0.03 \\
\hline & $\mathrm{CV}$ & & & & & & \\
\hline & Min & & & & & & \\
\hline & Max & & & & & & 0.04 \\
\hline \multirow[t]{4}{*}{ Temp } & Avg & & & & 0.02 & & \\
\hline & $\mathrm{CV}$ & & & & & NS & \\
\hline & Min & & & 0.04 & & & \\
\hline & Max & & NS & & & & \\
\hline \multirow[t]{4}{*}{ SpCond } & Avg & & & & & & \\
\hline & $\mathrm{CV}$ & & 0.01 & & 0.02 & & \\
\hline & Min & & & & & & $0.03(-)$ \\
\hline & Max & NS & NS & & NS & & \\
\hline
\end{tabular}

is unexpected, considering that numerous studies show that nitrate is influenced by land cover (Johnson et al. 1997, Paul and Meyer 2001). However, previous work in the Río Piedras also failed to identify factors related to stream nitrate concentrations (de Jesús-Crespo and Ramírez 2011, Potter et al. 2013). Potential explanations for a lower than expected nitrate concentration and a lack of increase with urban infrastructure in the Río Piedras might be related to the high availability of $\mathrm{NH}_{4}$ that is not nitrified to nitrate (Potter et al. 2013), and high denitrification rates in reaches where oxygen is low and dissolved organic carbon is high (Potter et al. 2010). Similar to our findings, studies in other tropical regions have found a lack of relation between land-use change and stream nitrate concentrations. In streams draining different land uses in Brazil, including some receiving inputs of untreated urban sewage, Ometo et al. (2000) found a lack of increase in nitrate concentrations and argue that denitrification might be responsible for the patterns observed.
The lack of strong seasonality observed for the Río Piedras is in accordance with its location within the subtropical moist forest life zone (Holdridge 1967). The annual air temperature pattern follows that of the northern hemisphere, with maximum temperatures during summer, e.g., July, August, and minimum during winter, e.g., January, February. Although the difference between average monthly air temperatures is only of around $4^{\circ}$ $\mathrm{C}$, the pattern is evident in stream water temperature (Fig. 4). Water temperature in the Río Piedras was as low as $22^{\circ} \mathrm{C}$ and as high as $30^{\circ} \mathrm{C}$. Watershed vegetation cover plays an important role determining stream water temperature, with differences among streams of at least $4^{\circ} \mathrm{C}$. Seasonality in rainfall and stream discharge is less defined. Although a dry season is normally delimited from January to May, rain events are likely to occur year round. Stream base flow was clearly higher from May to November (Fig. 3) in general accordance with a wet season. In addition, changes in discharge could be the reason for observed fluctuations in certain ion concentrations, e.g., calcium. 


\section{Relations with urban infrastructure}

Urban development in our study watershed was large and clearly reflected in the stream water chemistry. This strong urban signal was previously documented for nutrients in the Río Piedras watershed. Potter et al. (2013) found stream base flow concentrations of $\mathrm{NH}_{4}$, dissolved organic carbon, dissolved organic nitrogen, and $\mathrm{PO}_{4}$ to increase as urban infrastructure on the watershed increased. Also similar to our findings, they found that $\mathrm{NO}_{3}$ did not follow that pattern and instead decreased with increasing urbanization. The amount of urbanization required to produce the strong urban signal observed in Río Piedras was low. Of our eight sites, only the site with the lowest urban cover (site $1,13 \%$ ISA) grouped separately from the remaining sites in ordination space, the rest sharing similar chemistries. Previous studies have found that even minor amounts of catchment imperviousness are associated with clear changes in water chemical characteristics and ecological processes. For example, Tippler et al. (2012) found that sites with moderate levels of imperviousness ( 5 to $18 \%$ ) showed major differences in water chemistry and ionic concentrations compared to streams with less impervious surfaces. There is also extensive documentation on how biotic communities change as watersheds become urbanized. Walsh et al. (2007) found a decrease in taxa sensitive to pollution as imperviousness increased in the watershed, with these taxa rarely occurring in sites with $>4 \%$ total imperviousness. Other studies found linear responses between insect assemblage and urbanization, with changes in invertebrate assemblage beginning as soon as the native vegetation begins to be replaced with roads and buildings (Cuffney et al. 2005).

Similar to the gradient described for stream chemistry, the density of structures on the subwatershed also increased as percent impervious surface increased in the subwatershed. The fact that PCA axis 1 was significantly related to subwatershed structure densities suggests that urbanization is a major driver determining stream physicochemistry in the Río Piedras. Although urban areas are known to increase solute concentrations in rivers (Kaye et al. 2006), the mechanisms are diverse. Common mechanisms include excess use of fertilizers in gardening and green area maintenance, waste production, structure erosion, and leaking infrastructure (Wenger et al. 2009). In the Río Piedras Watershed, high solute concentrations might be the result of structure erosion (as previously described for calcium), leaking infrastructure, illegal discharges, and runoff. Several of the study sites were obviously receiving discharges contaminated effluents, sometimes smelling clearly of raw sewage inputs (K. Rosas, personal observation). Our findings are in accordance with the idea that although percent impervious surface remains an important predictor of water quality, urban watersheds are complex systems that change in space and time and with infrastructure management or deterioration, all those factors ultimately reflected in stream water characteristics (Kaushal and Belt 2012). For example, Carle et al. (2005) found that inclusion of variables describing the urban type and access to city services, such as sewer and storm water systems, helps to account for a wide range of sources of pollution and gives a more comprehensive picture of a complex urban environment with respect to its effects on water quality than any single variable taken alone. In the case of nutrients (e.g., $\mathrm{NO}_{3}$ and $\mathrm{NH}_{4}$ ), predicting their concentration in relation to urban infrastructure is much improved by the inclusion of ecosystem processes, such as nitrification, as part of stream network models (Potter et al. 2013).

Urban land use is rapidly increasing in the tropics, mostly the result of increasing work opportunities in industries that are often concentrated in or near cities (Montgomery 2008). The rapid pace of urbanization in the tropics highlights the importance of understanding its effects on stream ecosystems, both for ecological and management reasons. Puerto Rico went through an economic transition from an agricultural to an industrial economy in the 1940s (Grau et al. 2003). The island is now highly urbanized and most urban areas are serviced by sewage systems with suburban and rural areas relying on septic tanks. Urban sewage systems collect wastewater and move it to water treatment plants (some primary, a few tertiary) that often discharge to the ocean instead of discharging into rivers (Ortiz-Zayas et al. 2006). Even so, illegal discharges and leaky infrastructure are responsible for the elevated nutrient concentrations reported for urban rivers, as we found in the Río Piedras. This situation contrasts with most urban tropical rivers, where untreated sewage is almost always discharged directly into rivers (Daniel et al. 2002). Therefore, the conditions described in this study reflect urban effects to tropical stream ecosystems after the removal of some of the effects associated with direct sewage inputs. Overall, we can expect that even after sewage input removal, tropical urban streams in developing countries might continue to experience elevated nutrient and ion concentrations in comparison with forested watersheds. Proper infrastructure maintenance and management of runoff will therefore play a major role in controlling ion concentrations in tropical streams.

\section{Responses to this article can be read online at: http://www.ecologyandsociety.org/issues/responses. $\mathrm{php} / 6481$}

\begin{abstract}
Acknowledgments:
Thanks are due to Karleen Wagner for helping with sub watershed delimitations, Ana Arache for field sampling support, and the analytical laboratory at the International Institute of Tropical Forestry for sample analyses. Dr. W. H. McDowell provided advice on site selection, analytical techniques, and also commented on the manuscript. Support for this study was obtained from the San Juan ULTRA Program (NSF Grant No. 0948507), the USDA Forest Service International Institute of Tropical Forestry, and the Luquillo Long-Term Ecological Research program (DEB-0620910).
\end{abstract}

\section{LITERATURE CITED}

Alberti, M., J. M. Marzluff, G. Bradley, C. Ryan, E. Shulenberger, and C. Zumbrunnen. 2003. Integrating humans into ecology: opportunities and challenges for studying urban ecosystems. BioScience 53:1169-1179.

Allan, J. D. 2004. Landscapes and riverscapes: the influence of land use on stream ecosystems. Annual Review of Ecology, Evolution, and Systematics 35:257-284. http://dx.doi.org/10.1146/ annurev.ecolsys.35.120202.110122 
American Forests. 2002. Urban ecosystem analysis San Juan, Puerto Rico Metropolitan Area: calculating the value of nature. Report to USDA Forest Service International Institute of Tropical Forestry, San Juan, Puerto Rico.

Brasher, A. M. D. 2003. Impacts of human disturbances on biotic communities in Hawaiian streams. BioScience 53:1052-1060. http://dx.doi.org/10.1641/0006-3568(2003)053[1052:IOHDOB]2.0. $\underline{\mathrm{CO} ; 2}$

Carle, M. V., P. N. Halpin, and C. A. Stow. 2005. Patterns of watershed urbanization and impacts on water quality. Journal of the American Water Resources Association 41:693-708. http://dx. doi.org/10.1111/j.1752-1688.2005.tb03764.x

Cuffney, T. F., H. Zappia, E. M. P. Giddings, and J. F. Coles. 2005. Effects of urbanization on benthic macroinvertebrate assemblages in contrasting environmental settings: Boston, Massachusetts; Birmingham, Alabama; and Salt Lake City, Utah. American Fisheries Society Symposium 47:361-407.

Daniel, M. B., A. A. Montebelo, M. C. Bernardes, J. P H. B. Ometto, P. B. de Camargo, A. V. Krusche, M. V. Ballester, R. L. Victoria, and L. A. Martinelli. 2002. Effects of urban sewage on dissolved oxygen, dissolved inorganic and organic carbon, and electrical conductivity of small streams along a gradient of urbanization in the Piracicaba River Basin. Water, Air, and Soil Pollution 136:189-206. http://dx.doi.org/10.1023/A:1015287708170

Davies, P. J., I. A. Wright, O. J. Jonasson, and S. J. Findlay. 2010. Impact of concrete and PVC pipes on urban water chemistry. Urban Water Journal 7:233-241. http://dx.doi.org/10.1080/1573$\underline{062 X .2010 .484502}$

de Jesús-Crespo, R., and A. Ramírez. 2011. Effects of urbanization on stream physicochemistry and macroinvertebrate assemblages in a tropical urban watershed in Puerto Rico. Journal of the North American Benthological Society 30:739-750. http:// dx.doi.org/10.1899/10-081.1

Ellis, E. C. 2011. Anthropogenic transformation of the terrestrial biosphere. Philosophical Transactions of the Royal Society A: Mathematical, Physical and Engineering Science 369:1010-1035. http://dx.doi.org/10.1098/rsta.2010.0331

Grau, H. R., T. M. Aide, J. K. Zimmerman, J. R. Thomlinson, E. Helmer, and X. Zou. 2003. The ecological consequences of socioeconomic and land-use changes in postagriculture Puerto Rico. BioScience 53:1159-1168. http://dx.doi.org/10.1641/0006-3568 (2003)053[1159:TECOSA]2.0.CO;2

Hatt, B. E., T. D. Fletcher, C. J. Walsh, and S. L. Taylor. 2004. The influence of urban density and drainage infrastructure on the concentrations and loads of pollutants in small streams. Environmental Management 34:112-124. http://dx.doi.org/10.1007/ $\underline{\mathrm{s} 00267-004-0221-8}$

Haire, W. J. 1971. Flooding along the Río Piedras in the San Juan area, Puerto Rico. Hydrologic Investigations Map Series No. I. U.S. Department of the Interior, U.S. Geological Survey (WRD), San Juan, Puerto Rico.

Holdridge, L. R. 1967. Life zone ecology. Tropical Science Center, San José, Costa Rica.

Johnson, L. B., C. Richards, G. E. Host, and J. W. Arthur. 1997. Landscape influences on water chemistry in Midwestern stream ecosystems. Freshwater Biology 37:193-208. http://dx.doi. org/10.1046/j.1365-2427.1997.d01-539.x

Kaushal, S. S., and K. Belt. 2012. The urban watershed continuum: evolving spatial and temporal dimensions. Urban Ecosystems 15:409-435. http://dx.doi.org/10.1007/s11252-012-0226-7

Kaushal, S. S., P. M. Groffman, L. E. Band, C. A. Shields, R. P. Morgan, M. A. Palmer, K. T. Belt, C. M. Swan, S. E. G. Findlay, and G. T. Fisher. 2008. Interaction between urbanization and climate variability amplifies watershed nitrate export in Maryland. Enviromental Science and Technology 42:5872-5878. http://dx.doi.org/10.1021/es800264f

Kaye, J. P., P. M. Groffman, N. B. Grimm, L. A. Baker, and R. V. Pouyat. 2006. A distinct urban biogeochemistry? Trends in Ecology and Evolution 21:192-199. http://dx.doi.org/10.1016/j. $\underline{\text { tree.2005.12.006 }}$

Kwak, T. J., P. B. Cooney, and C. H. Brown. 2007. Fishery population and habitat assessment in Puerto Rico streams: phase 1 final report. Federal Aid in Sport Fish Restoration Project F50, Final Report, Department of Natural and Environmental Resources, San Juan, Puerto Rico.

Leung, C., and J. J. Jiao. 2006. Change of groundwater chemistry from 1896 to present in the Mid-Levels area, Hong Kong. Environmental Geology 49:946-959. http://dx.doi.org/10.1007/ s00254-005-0133-9

Lugo, A. E., O. M. Ramos-González, and C. R. Pedraza. 2011. The Rio Piedras Watershed and its surrounding environment. FS-980, U.S. Department of Agriculture, Forest Service, Río Piedras, Puerto Rico.

McCune, B., and M. J. Mefford. 1999. Multivariate analysis of ecological data. MjM Software, Version 4.25. Gleneden Beach, Oregon, USA.

McDowell, W. H., and C. E. Asbury. 1994. Export of carbon, nitrogen, and major ions from three tropical montane watersheds. Limnology and Oceanography 39:111-125. http://dx.doi. org/10.4319/10.1994.39.1.0111

McDowell, W. H., A. E. Lugo, and A. James. 1995. Export of nutrients and major ions from Caribbean catchments. Journal of the North American Benthological Society 14:12-20. http://dx.doi. org/10.2307/1467721

Meyer, J. L., M. J. Paul, and W. K. Taulbee. 2005. Stream ecosystem function in urbanizing landscapes. Journal of the North American Benthological Society 24:602-612. http://dx.doi. org/10.1899/04-021.1

Montgomery, M. R. 2008. The urban transformation of the developing world. Science 319:761-764. http://dx.doi.org/10.1126/ science. 1153012

Ometo, J. P. H. B., L. A. Martinelli, M. V. Ballester, A. Gessner, A. V. Krusche, R. L. Victoria, and M. Williams. 2000. Effects of land use on water chemistry and macroinvertebrates in two streams of the Piracicaba river basin, south-east Brazil. Freshwater Biology 44:327-337. http://dx.doi.org/10.1046/ j.1365-2427.2000.00557.x

Ortiz-Zayas, J. R., E. Cuevas, O. L. Mayol-Bracero, L. Donoso, I. Trebs, D. Figueroa-Nieves, and W. H. McDowell. 2006. Urban 
influences on the nitrogen cycle in Puerto Rico. Biogeochemistry 79:109-133. http://dx.doi.org/10.1007/s10533-006-9005-y

Osterkamp, W. R. 2001. Earth surface processes, materials use, and urban development: a case study of the San Juan metropolitan area, northeastern Puerto Rico. Water Resources Division, U.S. Geological Survey, Tucson, Arizona.

Paul, M. J., and J. L. Meyer. 2001. Streams in the urban landscape. Annual Review of Ecology and Systematics 32:333-365. http://dx. doi.org/10.1146/annurev.ecolsys.32.081501.114040

Pickett, S. T. A., M. L. Cadenasso, J. M. Grove, C. G. Boone, P. M. Groffman, E. Irwin, S. S. Kaushal, V. Marshall, B. P. McGrath, C. H. Nilon, R. V. Pouyat, K. Szlavecz, A. Troy, and P. Warren. 2011. Urban ecological systems: scientific foundations and a decade of progress. Journal of Environmental Management 92:331-362. http://dx.doi.org/10.1016/j.jenvman.2010.08.022

Potter, J. D., W. H. McDowell, A. M. Helton, and M. L. Daley. 2013. Incorporating urban infrastructure into biogeochemical assessment of urban tropical streams in Puerto Rico. Biogeochemistry. http://dx.doi.org/10.1007/s10533-013-9914-5

Potter, J. D., W. H. McDowell, J. L. Merriam, B. J. Peterson, and S. M. Thomas. 2010. Denitrification and total nitrate uptake in streams of a tropical landscape. Ecological Applications 20:2104-2115. http://dx.doi.org/10.1890/09-1110.1

R Development Core Team. 2014. R: A language and environment for statistical computing. $\mathrm{R}$ Foundation for Statistical Computing, Vienna, Austria. [online] URL: http:// www.R-project.org

Ramírez, A., R. de Jesús-Crespo, D. M. Martinó-Cardona, N. Martínez-Rivera, and S. Burgos-Caraballo. 2009. Urban streams in Puerto Rico: what can we learn from the tropics? Journal of the North American Benthological Society 28:1070-1079. http://dx. doi.org/10.1899/08-165.1

Ramírez, A., A. Engman, K. G. Rosas, O. Perez-Reyes, and D. M. Martinó-Cardona. 2012. Urban impacts on tropical island streams: some key aspects influencing ecosystem response. Urban Ecosystems 15:315-325. http://dx.doi.org/10.1007/s11252-011-0214-3

Santos-Román, D. M., G. S. Warner, and F. N. Scatena. 2003. Multivariate analysis of water quality and physical characteristics of selected watersheds in Puerto Rico. Journal of the American Water Resources Association 39:829-839. http://dx.doi.org/10.1111/ j.1752-1688.2003.tb04408.x

Tippler, C., I. A. Wright, and A. Hanlon. 2012. Is catchment imperviousness a keystone factor degrading urban waterways? A case study from a partly urbanised catchment (Georges River, South-Eastern Australia). Water, Air, and Soil Pollution 223:5331-5344. http://dx.doi.org/10.1007/s11270-012-1283-5

U.S. Census Bureau. 2010. Census data for Puerto Rico 2010. U. S. Census Bureau, Department of the Interior, Washington, D. C., USA. [online] URL: http://www.census.gov/2010census/ popmap/ipmtext.php?fl=72

Walsh, C. J., A. H. Roy, J. W. Feminella, P. D. Cottingham, P. M. Groffman, and R. P. Morgan II. 2005. The urban stream syndrome: current knowledge and the search for a cure. Journal of the North American Benthological Society 24:706-723. http:// dx.doi.org/10.1899/04-028.1

Walsh, C. J., K. A. Waller, J. Gehling, and R. M. Nally. 2007. Riverine invertebrate assemblages are degraded more by catchment urbanisation than by riparian deforestation. Freshwater Biology 52:574-587. http://dx.doi.org/10.1111/ j.1365-2427.2006.01706.X

Wenger, S. J., A. H. Roy, C. R. Jackson, E. S. Bernhardt, T. L. Carter, S. Filoso, C. A. Gibson, W. C. Hession, S. S. Kaushal, E. Marti, J. L. Meyer, M. A. Palmer, M. J. Paul, A. H. Purcell, A. Ramírez, A. D. Rosemond, K. A. Schofield, E. B. Sudduth, and C. J. Walsh. 2009. Twenty-six key research questions in urban stream ecology: an assessment of the state of the science. Journal of the North American Benthological Society 28:1080-1098. http:// dx.doi.org/10.1899/08-186.1

Wright, I. A., P. J. Davies, S. J. Findlay, and O. J. Jonasson. 2011. A new type of water pollution: concrete drainage infrastructure and geochemical contamination of urban waters. Marine and Freshwater Research 62:1355-1361. http://dx.doi.org/10.1071/ $\underline{\mathrm{MF} 10296}$ 